\title{
Influence of Type of Solar Modules Anchorages on Power of Solar Power Station
}

\author{
Olena Savchenko, Khrystyna Kozak ${ }^{*}$ \\ Lviv Polytechnic National University, 12, S. Bandery St., Lviv, 79013, Ukraine
}

Received: April 09, 2019. Revised: April 23, 2019. Accepted: May 29, 2019.

(c) 2019 The Authors. Published by Lviv Polytechnic National University.

\begin{abstract}
Electricity generation through solar power plants is one of the ways to Ukraine's energy independence. The amount of electricity generated by a solar power plant depends on the intensity of the solar radiation entering onto the solar module, the total area of the solar modules, and their efficiency. The intensity of solar radiation entering the solar module depends directly on the type of the solar module anchorages. In this article, the intensity of solar radiation, which enters onto the solar modules with different types of anchorages, is determined. It is established that the highest intensity of solar radiation enters onto the solar modules, which have a dynamic mount with two-axle trackers. The difference between the dynamic type of fastening with one-axis and two-axis trackers is practically absent in the warm period of the year; in the cold period of the year, a dynamic mount with a two- axis tracker allows you to increase the amount of solar radiation entering the solar module to $30 \%$. Compared to a stationary anchorage, the dynamic anchorage of solar modules allows you to increase the intensity of solar radiation that enters onto the solar module to $67 \%$.
\end{abstract}

Keywords: solar power station; stationary anchorage; dynamic anchorage; one-axis tracker; two-axis tracker.

\section{Introduction}

The production of electricity through solar power plants is currently practiced around the world. Many factors contribute to this, the main ones being the rise in price of traditional energy sources, the harmful effects of greenhouse gases on the environment. The development of solar energy in the territory of Ukraine is additionally stimulated by the state through the green tariff, which obliges the state to purchase electricity from renewable energy sources, in particular solar energy, from commercial and private organizations. Solar power plant is a complex of engineering equipment that serves to convert solar energy into electricity. If solar energy is directly converted into electrical energy, then such solar power plants are called photoelectric, and their main elements are solar modules. Photoelectric solar power plants can be installed on land plots and on buildings, in particular on roofs of residential houses or cottages. They can be used as additional power supplies, or completely autonomous [1]. Solar power stations not connected with the industrial electrical network, in which the generated energy is accumulated in accumulative batteries and is spent only on the needs of the household, are called autonomous solar power plants. In the network of solar power plants, the energy generated is spent on the household needs, and the surplus is redeemed by the state at a green tariff, and there are no accumulative batteries in the network station. There are also hybrid solar power plants in which the energy generated is spent on the household needs, and the surplus is redeemed by the state at a green tariff and accumulates in batteries.

\footnotetext{
* Corresponding author. Email address: cr i@ukr.net
}

This paper should be cited as: O. Savchenko, K. Kozak. Influence of type of solar modules anchorages on power of solar power station. Energy Engineering and Control Systems, 2019, Vol. 5, No. 1, pp. 23 - 28. https://doi.org/10.23939/jeecs2019.01.023 
The amount of electrical energy produced by a photovoltaic solar station depends on the intensity of solar radiation entering onto the photoconverter of the solar module, the total area of the solar modules, and the photoconverters efficiency. The efficiency of the photoconverter depends on the type of semiconductor materials and the design of the solar module. For the production of semiconductor photoconverters, silicon is most often used. The highest efficiency of the conversion of solar energy into an electric current, $14-20 \%$, has a module based on structured monocrystalline silicon, modules based on polycrystalline cast-silicon have an efficiency of $13-15 \%$, modules on the basis of thin film silicon - efficiency of 6-10\% [2].

The intensity of solar radiation entering onto the solar module depends on the intensity of solar radiation in the building area and the type of installation of solar modules. The installation of solar modules takes place on special constructions, which ensure their optimal orientation to the Sun and reliable attachment to different types of surfaces: ground foundations, roofs, vertical surfaces. There are two main types of solar modules anchorages: stationary and dynamic [3]. With stationary anchorage, the orientation of the modules and the angle of their inclination towards the Sun cannot be changed, so the solar modules should be oriented toward the south. With dynamic anchorage there is a movement of solar modules during the motion of the Sun. The solar modules motion is carried out by trackers, which depending on the number of axes of rotation, is one-axis and two-axis. The axis of rotation of a one-axis tracker is usually oriented along the north-south axis. Two-axis trackers allow you to observe the Sun vertically and horizontally at the expense of two axes of rotation. For maximum energy efficiency, photovoltaic modules should be mounted in such a way that the sun's rays fall to the working surface of the module at an angle of $90^{\circ}$.

\section{Aim of the research}

The aim of the work is to determine the intensity of solar radiation entering onto the solar modules, depending on the type of fastening, and the effect of the type of fastening on the power of the solar power station.

\section{Analysis of recent research and publication}

The main elements of the solar power station are solar modules, controller, accumulator batteries and inverter [4]. Solar modules convert solar radiation into a constant electric current, which is fed to the controller. The controller automatically sets the optimal constant electric current settings for charging the batteries. In addition, the controller regulates the supply of energy from solar modules, thus preventing the battery from being completely discharged. Controller automatically shuts off the accumulation of batteries from the system when they fully are charged. When the accumulative batteries are fully charged, the excess electricity is supplied to the inverter connected to the alternating current consumers. In the absence of solar radiation, electricity from accumulating batteries is supplied to the inverter, which turns into a variable and then feeds alternating current consumers.

Solar power plant alternating current can operate in three modes:

- autonomous electricity supply, used in the absence of alternating current network. All accumulated light day electricity in accumulative batteries is used in the evening and night time for power supply of alternating current consumers;

- mixed electricity supply. Lack of electric energy in accumulating batteries is offset by electric current from the alternating current network.

- backup electricity supply. The solar power plant involves setting the inverter so that when accumulating the batteries are always $100 \%$ charged. Only a small amount of solar energy is consumed in support of full charge of batteries, the rest of the volume is converted into alternating current and used to power consumers, the excess is given to the network, in accordance with the terms of the "green" tariff.

For the maximum productivity of a solar power station, the plane of the solar module must always be perpendicular to the sun's rays. However, the Sun always shines on the Earth's surface at different angles, depending on the time of day and year. To determine the position of the solar module, the following basic angular parameters are taken into account: geographic latitude of the construction site $\varphi$; hour angle $\tau$; declination $\delta$; azimuth $\alpha$; angle of inclination to the horizon $\beta[5,6]$.

The hour angle translates local sun time into the number of degrees that the sun passes through the sky. The Earth returns by $15^{\circ}$ in one hour; therefore, the hour angle in midday is zero, in the morning it is negative, in the evening it is positive. 


$$
\tau=15 \cdot\left(12-\mathrm{T}_{\mathrm{s}}\right)
$$

where $T_{s}$ is solar time, hours, which is determined by the formula:

$$
\mathrm{T}_{\mathrm{s}}=\mathrm{T}_{1}-\frac{\mathrm{EOT}}{60}-\mathrm{P}-\mathrm{LC},
$$

where $T_{1}$ is local time; $\mathrm{P}$ is coefficient that takes into account the daylight saving time, for months from November to March $\mathrm{P}=0$, from April to October $\mathrm{P}=1$; EOT is equation of time.

The expression for determining the equation of time will have the form:

$$
\mathrm{EOT}=60 \sum_{\mathrm{k}=1}^{6}\left[\mathrm{Ak} \cdot \cos \left(\frac{360 \mathrm{kn}}{365.25}\right)+\mathrm{Bk} \cdot \sin \left(\frac{360 \mathrm{kn}}{365.25}\right)\right],
$$

where $\mathrm{n}$ is the sequence number of the day in the year in the leap year cycle; $\mathrm{k}, \mathrm{A}, \mathrm{B}$ are coefficients which are taken from literature [6].

To simplify the calculations of the EOT can be taken on the tables in the reference literature.

LC can be determined by the formula:

$$
\mathrm{LC}=(\text { Local Longitude }- \text { Longitude of Standart Meridian }) / 15,
$$

The declination angle depends on the rotation of the Earth around the Sun, since the orbit of rotation has an elliptical shape and the axis of rotation is also inclined, then the angle varies during the year and is $23,45^{\circ} \ldots-23,45^{\circ}$. The declination angle becomes zero twice a year in the days of spring and autumn equinox. The declination angle $\delta$ in this day $\mathrm{N}$ each month is determined by Cooper's formula:

$$
\delta=23.45 \cdot \sin \left(360 \frac{284+\mathrm{N}}{365}\right)
$$

where $\mathrm{N}$ is ordinal number of the day in the year, deducted from January 1st.

The angle that determines the height of the Sun above the horizon at a given time is called solstice height. It depends on the magnitude of the angle of inclining the Sun, the hour angle and the geographical latitude of the terrain and is determined by the formula:

$$
\mathrm{h}_{\mathrm{c}}=\arcsin (\sin \delta \cdot \sin \varphi+\cos \delta \cdot \cos \tau \cdot \cos \varphi) .
$$

Azimuth characterizes the deviation of the absorbing plane of the solar module from the southern direction, for orientation of the solar collector exactly to the south $\alpha=0^{\circ}$. The angle of inclination to the horizon $\beta$ is formed between the horizontal plane and the solar module. The angle of inclination to the horizon $\beta$ is determined by the calculation method and depends on the type of anchorage of solar modules and the period of use of the solar system. With stationary anchorage of solar modules at their southern orientation for year-round heliosystems $\beta=\varphi$, for seasonal heliosystems $\beta=\varphi-15^{\circ}[7]$.

The use of dynamic anchorages of solar modules allows you to orientate their active surface as effectively as possible and significantly increase the performance compared to stationary anchorage on fixed metal constructions [8]. The tracker is selected depending on the operating conditions, including: latitude, weather conditions, installation dimensions, available installation area, etc. The main task of the solar tracker is the need to achieve the most qualitative rotation of the platform at right angles to the sun's rays. Trackers are distinguished by the number and position of the axes of rotation (Fig. 1). In one-axis trackers, the axis of rotation can be located in any coordinate directions and use any tracking algorithm, for example trackers with horizontal, vertical, with a slope and with a polar-oriented axis of rotation. Two-axis trackers more closely monitor the position of the Sun, controlling both the azimuth angle and the angle of the Sun's inclination above the horizon. 


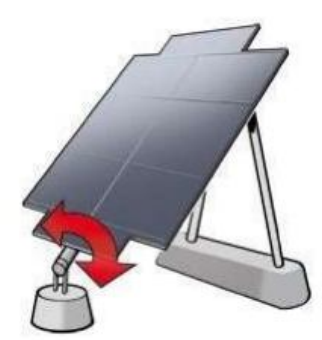

1

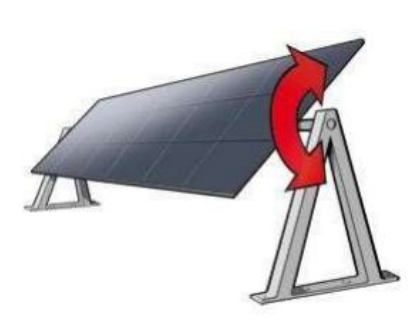

2

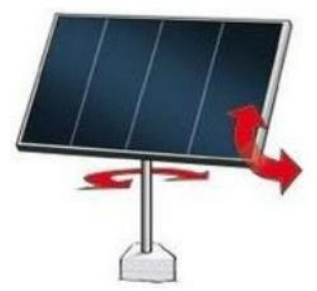

3

Fig.1. Tracker schemes:

1 - one-axis tracker with a sloping axis of rotation; 2 - one-axis tracker with a horizontal axis of rotation; 3 - two-axis tracker

The tracker can follow the sun in three ways: manually, with the use of photo transmitters and automatically. The simplest and most reliable way is to manually position the tracker. This method is least effective, but the lack of measuring equipment and a minimum of moving parts make it as reliable as possible. Orientating a tracker using a photodetector is simple, but unreliable, because it has many disadvantages: the sensors are often polluted, resulting in cease to work, require calibration, the system does not work in cloudy weather, the presence of mechanical problems during operation. The most reliable is the automatic way of controlling solar modules, in which the orientation of solar modules is programmed in accordance with the cycles of the Sun's motion. The use of dynamic tracker systems for anchorage solar modules requires high capital costs, additional maintenance, a large area for installing and consuming additional energy, so often in Ukraine solar power plants often use stationary anchorage of solar modules.

\section{Main material}

The power of the solar photovoltaic power plant, $\mathrm{kW}$, is determined by the formula:

$$
\mathrm{P}=\mathrm{Sr} \cdot \mathrm{F} \cdot \eta
$$

where $\mathrm{Sr}$ is the intensity of solar radiation entering the solar modules, $\mathrm{kW} / \mathrm{m}^{2} ; \mathrm{F}$ is area of solar modules, $\mathrm{m}^{2} ; \eta$ is coefficient of efficiency of photoconverters of solar modules.

The intensity of solar radiation entering onto the solar modules depends on anchorage type:

- when using a dynamic anchorage with two-axis control system. In this case, the surface of the solar module is directed toward the Sun, and, consequently, the declination angle of the Sun $\beta=0$, then:

$$
\mathrm{Sr}^{\mathrm{II}}=\mathrm{Sr}_{\max } \cdot \mathrm{K}_{\mathrm{am}}
$$

- when using a dynamic anchorage with one-axis control system:

$$
\mathrm{Sr}^{\mathrm{I}}=\mathrm{Sr}_{\max } \cdot \mathrm{K}_{\mathrm{am}} \cdot \cos \left(\varphi-\mathrm{h}_{\mathrm{c}}\right)
$$

- when using a stationary anchorage and installing a solar module at an angle:

$$
\mathrm{Sr}_{\mathrm{st}}=\mathrm{Sr}_{\max } \cdot \mathrm{K}_{\mathrm{am}} \cdot \cos \left(\varphi-\mathrm{h}_{\mathrm{c}}\right) \cdot \cos (90-\tau)
$$

where $\mathrm{Sr}_{\max }$ is the amount of solar radiation entering onto the Earth (this value is a solar constant and equals $1325 \mathrm{~W} / \mathrm{m}^{2}$, but $30-35 \%$ of this energy is reflected back into space, so we accept $\mathrm{Sr}_{\max }=925 \mathrm{~W} / \mathrm{m}^{2}$ ); $\mathrm{K}_{\mathrm{am}}$ is correction for the air mass, which must be passes by the sun ray:

$$
\mathrm{K}_{\mathrm{am}}=1.1254-\frac{0.1366}{\sin \mathrm{h}_{\mathrm{c}}}
$$


For the comparison of the intensity of solar radiation entering onto solar modules with different anchorage types, the intensity of solar radiation for the solar module, which is installed in Lviv, is determined.. Geographical coordinates of Lviv are accepted: geographical latitude $\varphi=49^{\circ}$, geographical longitude $24^{\circ}$. Then, LC $=24 / 15=1,6$. The calculation was made for the first day of each month. The results of calculations of the intensity of solar radiation coming to solar modules with different anchorages types are given in Table 1.

Table 1 . The intensity of solar radiation for different anchorages types of solar modules.

\begin{tabular}{|l|c|c|c|c|c|c|c|c|c|c|c|c|}
\hline \multicolumn{1}{|c|}{ Month } & 1 & 2 & 3 & 4 & 5 & 6 & 7 & 8 & 9 & 10 & 11 & 12 \\
\hline \hline Day of the year & 1 & 32 & 60 & 91 & 121 & 152 & 182 & 213 & 244 & 274 & 305 & 335 \\
\hline$\delta$, degree & -23.03 & -17.63 & -8.23 & 4.00 & 14.81 & 22.09 & 23.03 & 17.86 & 7.76 & -4.23 & -15.28 & -22.09 \\
\hline Ts, hour & 10.34 & 10.17 & 10.19 & 10.33 & 9.45 & 9.44 & 9.34 & 9.30 & 9.40 & 9.57 & 9.67 & 10.59 \\
\hline$\tau$, degree & 24.85 & 27.40 & 27.13 & 25.03 & 38.28 & 38.40 & 39.90 & 40.58 & 39.05 & 36.48 & 34.90 & 21.20 \\
\hline $\mathrm{h}_{\mathrm{c}}$ & 10.88 & 15.99 & 25.86 & 40.03 & 42.47 & 47.68 & 47.57 & 43.82 & 36.66 & 26.52 & 15.91 & 12.46 \\
\hline $\mathrm{K}_{\mathrm{am}}$ & 0.406 & 0.629 & 0.812 & 0.913 & 0.923 & 0.941 & 0.940 & 0.928 & 0.897 & 0.819 & 0.627 & 0.493 \\
\hline $\mathrm{Sr}^{\mathrm{II}}, \mathrm{kW} / \mathrm{m}^{2}$ & 376 & 582 & 751 & 844 & 854 & 870 & 870 & 858 & 829 & 758 & 580 & 456 \\
\hline $\mathrm{Sr}^{\mathrm{I}}, \mathrm{kW} / \mathrm{m}^{2}$ & 296 & 488 & 691 & 834 & 849 & 870 & 870 & 855 & 810 & 700 & 486 & 366 \\
\hline $\mathrm{Sr}_{\mathrm{st}}, \mathrm{kW} / \mathrm{m}^{2}$ & 124 & 225 & 315 & 352 & 525 & 540 & 558 & 556 & 510 & 416 & 278 & 133 \\
\hline
\end{tabular}

For same area of solar modules and the efficiency of photoconverters of solar modules, the power of a solar power plant will be greater for those cases where the intensity of solar radiation entering solar modules is greater. As can be seen from Table 1, the highest intensity of solar radiation enters onto solar modules, which have a dynamic anchorage with two-axis trackers. Therefore, under other identical conditions, the greater power of a solar power plant will be with dynamic anchorage with two-axis trackers.

As a result of Table 1, a histogram of intensity of solar radiation, which enters the surface of the solar module, depending on the month of the year and the anchorage types of the solar modules, is shown in Fig. 2.

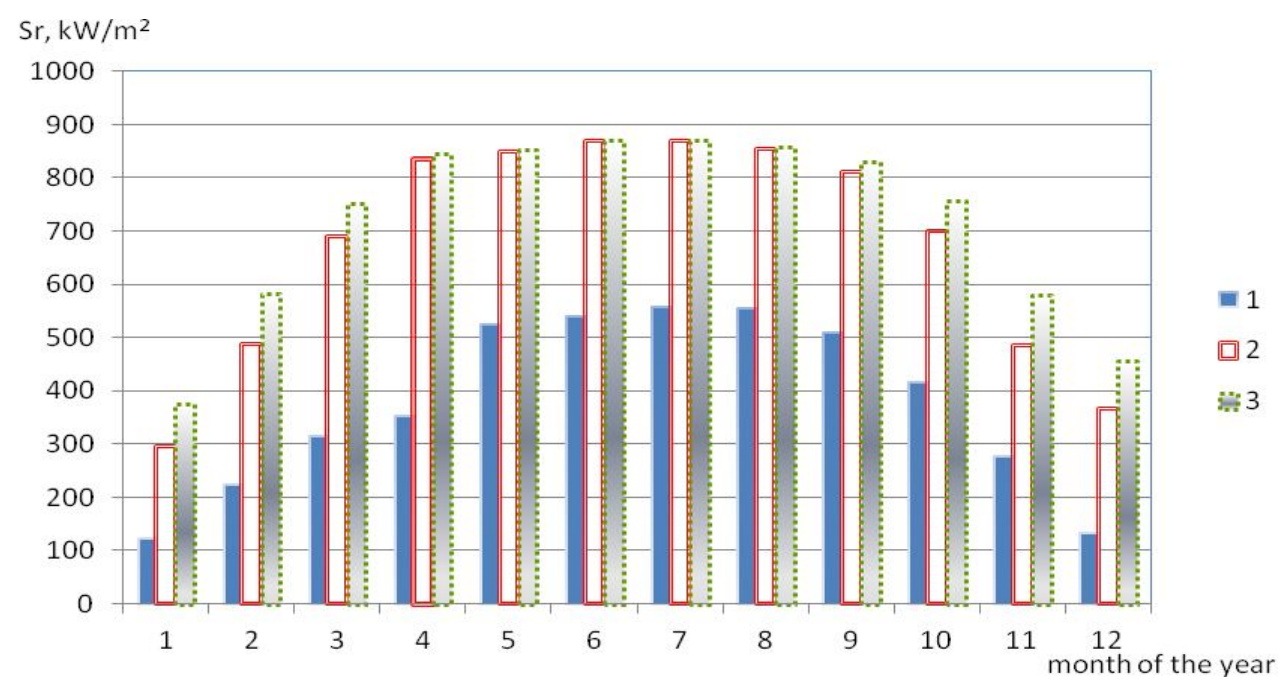

Fig.2. The intensity of solar radiation coming to the surface of the solar module depending on the month of the year and the anchorage types of the solar modules:

1 - stationary anchorage; 2 - dynamic anchorage with one-axis tracker; 3 - dynamic anchorage with two-axis tracker.

As can be seen from Fig. 1, the highest intensity of solar radiation enters onto solar modules, which have a dynamic anchorage with one-axis trackers. The difference between the dynamic anchorage with one-axis and twoaxis trackers is practically absent in the warm period of the year, but in the cold period of the year, the dynamic anchorage with a two-axis tracker allows you to increase the intensity of solar radiation that enters onto the solar module to $30 \%$. Compared to a stationary anchorage, the dynamic anchorage of solar modules allows you to increase the intensity of solar radiation that enters onto the solar module to $67 \%$. The greatest effect from the establishment of dynamic anchorages types is observed in the cold period of the year. 


\title{
5. Conclusion
}

This article defines the intensity of solar radiation coming onto solar modules with different anchorage types, in particular stationary anchorage and dynamic anchorage with one-axis and two-axis trackers. It is established that the highest intensity of solar radiation enters onto the solar modules, which have a dynamic anchorage with two-axis trackers, and the greatest effect from the establishment of dynamic types of fastening is observed in the cold period of the year. The difference between the dynamic anchorages types with one-axis and two-axis trackers is practically absent in the warm period of the year, but in the cold period of the year, the dynamic anchorage with a two-axis tracker allows you to increase the amount of solar radiation that enters onto the solar module to $30 \%$. Compared to a stationary anchorage, the dynamic anchorage of solar modules allows you to increase the intensity of solar radiation that enters onto the solar module to $67 \%$. And although the intensity of solar radiation depends on the anchorage type of solar modules, however, when installed solar modules on solar power plants, it is necessary to take into account the economic performance of the stated anchorage types.

\section{References}

[1] Savchenko, O. O., Kozak, Kh. R., Fedak, Yu. T. (2018) Autonomous Solar Power Plant for the ACMB House. Bulletin of Lviv Polytechnic National University. The theory and practice of construction, 888, 117-122. (in Ukrainian)

[2] Kashkarov, A. (2015) Solar panels and modules as power supplies. Modern electronics. 5, 8-15. (in Russian)

[3] Danko, V. M., Smutko, S. V., Polishchuk, O. S. (2017) Development of the design of the tracker system for solar panels. Bulletin of the Khmelnytsky National University, 1 (245), 232 - 235. (in Ukrainian)

[4] Gnatov, A. V., Argun, S. V. (2017) Analysis of schemes of solar power plants on photoelectric modules for accumulative stations of electric cars. Automobile transport, 41, 163-169. (in Ukrainian)

[5] Prinsloo, G., Dobson, R. (2015) Solar tracking. 542 p.

[6] Petrov, L. A. (2011) Solar Tracking Strategies. BSc (Hons) Dissertation. 80 p.

[7] Yarmolyuk, O. S., Zamkovyy, P. O. (2013) Calculation of output power of the solar panel taking into account the uncertainty of information. Power engineering. Ecology. Man. Scientific works of NTUU "KPI", pp. 411-418. (in Ukrainian)

[8] Samaulah, H., Basir, Y., Helmi, M., Faturrizky, F., Sugawara, A. (2018) Efficiency Analysis of Tracking and Stationary Solar Panel Modes Against Solar Radiation. Journal of Engineering Sciences, 5 (1), pp. H23-H28. http://dx.doi.org/10.21272/jes.2018.5(1).h4

\section{Вплив типу кріплення сонячних модулів на потужність сонячної електростанції}

\author{
Олена Савченко, Христина Козак \\ Наиіональний університет «Львівська політехніка», вул. С. Бандери, 12, Львів, 79013, Україна
}

\begin{abstract}
Анотація
Вироблення електричної енергії за допомогою сонячних електричних станцій є одним з шляхів до енергетичної незалежності України. Кількість електричної енергії, що вироблясться сонячною електростанцією, залежить від інтенсивності сонячного випромінювання, що надходить на сонячний модуль, загальної площі сонячних модулів та їх коефіцієнта корисної дії. Інтенсивність сонячного випромінювання, що надходить на сонячний модуль, безпосередньо залежить від типу кріплення сонячного модуля. В даній статті визначено інтенсивність сонячного випромінювання, яка надходить на сонячні модулі з різним типом кріплення. Встановлено, що найбільша інтенсивність сонячного випромінювання надходить на сонячні модулі, які мають динамічне кріплення з двовісними трекерами. Різниця між динамічним типом кріплення 3 одновісними та двовісними трекерами в теплий період року практично відсутня, в холодний період року динамічне кріплення 3 двовісним трекером дозволяє збільшити кількість сонячного випромінювання, що надходить на сонячний модуль до $30 \%$. У порівнянні зі стаціонарним кріпленням динамічне кріплення сонячних модулів дозволяє збільшити інтенсивність сонячного випромінювання, яке надходить на сонячний модуль, до $67 \%$.
\end{abstract}

Ключові слова: сонячна електростанція; статичне кріплення; динамічне кріплення; одновісний трекер; двовісний трекер. 